\title{
Architecture as the Art of Protecting the Innermost*
}

\author{
Igor Bondarenko \\ Scientific Research Institute of Theory and History of Architecture and Urban Planning \\ Branch of the Central Institute for Research and Design \\ Ministry of Construction and Housing and Communal Services of the Russian Federation \\ Moscow, Russia \\ E-mail: igor.bondarenko.54@mail.ru
}

\begin{abstract}
Architecture embodies the primal syncretic art of the living space arrangement. The beginnings of many more particular types of artistic activities can be found in this art. People, getting more and more self-confident and carried away by the bright and diverse fruits of their work, start to forget the fundamental meaning and purpose of the "mother of arts" - architecture, turning it into a "service", and not spiritual but technical and utilitarian one. This report aims to clarify the fundamental protective function of architectural and construction activities. It will be a question of reproduction of the act of the creation of space among chaos, in other words, of the enclosure of the space suitable for living, and its physical and speculative sheltering from "external darkness". From this point of view, the interior is the dominant element of an architectural work, and the exterior is a secondary, service and defensive one. Brutal fortifications and blind walls of the castle like houses are the clear evidence of that. Expressive architectural decoration owes its origin also to the tasks of protecting the inner chambers from the penetration of external evil forces. Frightening appearance of buildings served as reliable magic protection for their inhabitants. At the same time, architectural splendor had a meaning as a means of expressing the imperturbable greatness of a powerful God or a divine ruler. In any case, professional means of organizing architectural masses were aimed at protecting and presenting the spaces enclosed in these masses. Architecture, thus, played a role of both symbolic, and quite real apotrope for the sacred hearth of true life hidden inside. Awareness of this fact should help, at least partly, to return to contemporary architecture the status of a great life-building art.
\end{abstract}

Keywords-architecture; art; space; mass; space; chaos; image; external; internal; profane; sacred

\section{INTRODUCTION}

Architecture embodies the primal syncretic art of the living space arrangement. The beginnings of many more particular types of artistic activities, evolved over time can be found in this art. However, this originally sacramental spiritual and practical activity with the advent of a New, and

*The Reported study was Funded by Science and Technology

Development State Program of the Russian Federation for years 2013-2020 Program of Fundamental Research of State Academies of Science for years 2013-2020, within the Program of Fundamental Researches of Ministry of Construction, Housing and Utilities of the Russian Federation and Russian Academy of Architecture and Construction Sciences; the Research Project 1.2.1 even more Newest times began to lose its former meaningful mysteriousness, as secular rationalist thinking prevailed. People, getting more and more self-confident and carried away by the bright and diverse fruits of their work, start to forget the fundamental meaning and purpose of the "mother of arts" - architecture, turning it into a "profane service". Nowadays we have come to the situation that more and more often we hear skeptical statements about the present and the future of architecture, which has lost its positions, fell out of the sphere of culture and art, enslaved by the construction complex, lost its specificity and necessary autonomy, turned into a design, props, and therefore has died or is close to that state [1]. In order to better understand what is happening and try to restore the prestige of the profession, it is useful to turn to the origins, to the long-forgotten past, which can suddenly turn into something new and extremely relevant. This article will focus on the fundamental protective function of architectural and construction activities

\section{MASS AT THE SPACES' SERVICE}

In traditional cultures, the skill of the architect correlated with the act of the divine creation of the cosmos in the midst of chaos [2]. The meaning of this act was to enclose a space suitable for life. The most important thing was to create a strong shell that reliably protects the grace-filled light inside from the disastrous "outer darkness". No wonder the sky in the Bible is called solid. And the earth as the bottom of the universe was also, of course, solid. And on the perimeter "edges" of sky and earth had fit snugly to each other and "stuck" as it is written in the famous "Christian Eopography" of Cosmas Indikoplov [3]. So it naturally recalled the image of the wall and pillars or towers.

In the popular "charms" dating back to pagan magic there are very striking, dreamlike images of impregnable stone, iron or damask fences "rising from the earth to the sky", with fire, sparks and arrows, smashing enemies and making absolutely invulnerable those who were inside. Land and the sky were portrayed verbally, accordingly in the form of metal armour [4]. However, the protective sheath of be spelled one could be quite thin and soft, like a veil or the robe of the virgin, which had, however, admittedly, exceptional divine power [5]. The firmament was characterized in biblical texts and legends as a massive stone construction, as ice or glass surface, or sometimes as a 
light cloth or leather, spreaded above ground. The strength of the sheath and coating was provided, thus, not so much physically but by mystical means. Everyone knew that the greatest Lords protection was invisible and intangible.

From what was said above it becomes clear that the dominant element of the architectural structure is its interior, the interior space designed to shelter the inhabitants. And the exterior is designed to play a secondary, service and defensive role. The original tradition of locating the house owner's chambers in the depths of the home also confirms this statement. Place at the entrance was always considered inferior in rank. Every owner strove to move his mansion away from the street. Peter the Great's order to put the houses on the red lines was clearly not to the liking of Russian people. No wonder everyone who could afford it, immediately began to arrange court d'honneur in order to push the house deeper to the site and leave only wings and gates near the streets. That was the way how ancient national customs adapted to europeanizing norms and new urban requirements.

It should be noted that in the European urban development no one also tried to put the family life on display. On the contrary, it was hidden in the courtyards and adjacent rooms. So shops, offices, workshops and, of course, premises for protection, as well as facilities for renting were turned to the streets. In other words, it only seemed that the houses in Europe were "a solid facade", as expressed by Russians. That is true that the front of the houses often turned out to be one line, but they were not our huts, but the expanded and docked structures framing the dwellings and courtyards. In fact, they were fences with office premises attached to them inside and outside.

The history of the formation of family castles, reborn over time in the elegant palaces clarifies this issue well. They were given a rugged fortress like look in the early middle ages. When the military threat had passed and the worldview has changed, embrasures, began to transform into large windows and lush architectural facade decorations appeared. The creation of Palace anfilades behind these facades can be considered the metamorphosis of the fortress casemates, united by the perimeter corridor of militarydefensive purposes. The presence of a courtyard in both typologies definitely indicates the genetic relationship between palaces and castles. Moreover, one did not get into it through the surrounding premises, but through a special entrance arch - a kind of a gate passing through the city fortifications.

The principle of a Renaissance-Baroque Palace construction was extended to ordinary urban development of the new time, which is characterized by arrays of houses flanking the courtyard which residential entrances usually face. The monumental palaces of the nobility, which were transformed castles, certainly influenced the formation of such apartment buildings, and in Soviet times - municipal houses. However, it can be noted that at the general structural level, large palaces were resembling the smaller ones, and those - the most ordinary residential yards, from which the fabric of any traditional settlement was composed.
Therefore, it makes sense to talk about the successive development of the type of a city house from a residential courtyard surrounded by a fence with services built into it. In fact, it was a manor house, only clenched on all sides and forced to grow up.

It is important for us to understand the general logic of the formation and transformation of such universal volumetric structural unit. It is based on care about the enclosure of localized space with walls and buildings or many rows of walls - for greater reliability. The centers of big cities were framed just on this principle with a lot of crowded houses, sometimes forming something like mazes, and also several rows of fortifications. In small yards all this was simplified up to the usual fence and the minimum number of buildings.

But the theme of "folding" and the closure of space within certain boundaries did not end there. A separate building was built on the same principle: its walls protected the inner cavity, designed for peaceful living. Unlike the city opened to the sky, the building received the model of firmament - a roof. Residential yards, including household services, sometimes have been covered too.

Generalizing, it is possible to state that in each architectural and town-planning object the idea of the creation of a reliable cover of internal space was embodied. Anyway embedding one into another on the principle of matryoshka, these objects created a consistent hierarchy of such spaces, ending with the smallest, but especially revered and sacral ones. In the Christian city the last saving stronghold was the church, and - the altar inside the church. And the purest place was kept for praying in every house. On a town-planning scale, graveyards and monasteries served as guardians of the most sacred sites. In pagan times, this role was claimed by the special cult places.

\section{ARCHITECtURAL CAMOUfLAGE AND AGGRESSION}

It becomes clear enough why builders could pay little attention to the outer appearance of a building or structure. If there is a hostile world outside, why turn beautiful facades to it? Gloomy impregnable walls without windows and doors are more suited for protection. Characteristically, the ancient strongholds often got additions of the circles of chambers with entrances facing inward, which is natural. Nomadic camps are arranged in the same way with tents rear parts looking out of the circle. This reminds a similar formation of buffalo herds for protection of the calves from predators.

It is useful to recall the eerie image of a rotating BabaYaga's hut, where not even a crack can be found on the surface and which can be opened only to those who know the spell [6]. Let's pay attention to the fact that the hero of the fairy tale should make this hut stop and open the door. $\mathrm{He}$ is not interested to walk around it and go further, he must certainly go inside, because it contains the desired other world.

Ancient wood-earthen and stone fortress with a small number of well-protected, and even better - disguised gates 
and narrow embrasures caused a frightening impression Medieval keeps can be considered as their essence. Residential yards with "blind" walls were built on the same principle. Single houses has also become "blind" when shutters of their windows were closed. All their beauty was inside.

Traditions of hiding exquisitely decorated interiors and fragrant gardens, embodying the image of Paradise behind blank walls, which are still observed in the Arab world are significant in this regard. This contrast of internal and external spaces is emphasized by different attitude to pureness. One should clean and educate the inner world as the very soul of a man, while all the dirt should stay outside.

According to the ancient christianized set of household rules, Domostroy, every host and hostess was in every way to take care of decency and cleanliness. Here is a quote, ending with a comparison of a well-tended home of Paradise: "The good host's and hotes house is always clean and well and servants clean the yard from dirt and snow. And there should be no mess, and the stables and cowsheds should be well maintained. So one can enter the clean house as he enters Heaven [7].

In some places the custom of burning bonfires, getting rid of old useless things, in the spring survived until the twentieth century [8]. It resembled a festive farewell to winter, accompanied by the burning of the effigies of corresponding mythological characters. In addition, at the appointed hour the old fire was extinguished in all furnaces and by joint efforts, in the traditional way, as a rule, by friction, a new- clean fire was produced and carried to homes in order to be maintained there the whole next year [9]. It turns out that the fire itself eventually loses its purity, ages, deteriorates, so it has to be rejuvenated. To this we must add an ethnographic evidence on the prohibition to say a bad word near a home hearth, so as not to spoil the fire [10].

The fire in the hearth symbolized life, and its accidental fading was an ominous omen. The house abandoned for some sins turned out to be a haven of evil forces. Such deserted houses were met in the old days, and the locals were very afraid of them [11]. From this fact it follows that the architecture could become, at times, antihuman with all the ensuing consequences. Such houses where black healers and sorcerers lived also had bad reputation. No wonder they were located, as a rule, somewhere on the outskirts.

Houses of the dead, tombs and mausoleums are also in this list. They were similar to the houses and palaces of the living, although endowed with signs of memorials. Their builders also showed the art of protection, concealment and, at the same time, a worthy presentation of the hidden. The dead relatives were revered and deified, prayed for them and summoned for help. At the same time, they were afraid of and therefore people tried to localize their abode at a distance, in special places as cemeteries. And very closely followed those of them who not found rest and at night came out of the grave. For protection from evil forces, which was rampant at night, not only the high strong fences, blank walls and roof, tight doors, window shutters, kiln damper were needed. Magical protection in the form of all sorts of charms or talismans was required.

Mysticism in traditional cultures intertwined with everyday practicality. The most ordinary people could be friends for someone, and enemies and robbers for others. Any stranger posed a threat to the local community, as he was not tied with mutual obligations to it. Folklore well helps to understand how an obviously positive character is the bearer of evil for the Baba-Yaga, Zmey or Koshchey. Traveling to some "far-off land", he faces all sorts of obstacles that seem to be quite understandable defensive boundaries of foreign possessions. How to pass them? With relevant knowledge and wit, and well, not without magical assistants. One cannot so easily kill grinning monsters at the entrance. But they can be pacified with cherished word, persuaded, appeased, cajoled, so they would let the alien in, and so he would be accepted according to the laws of hospitality.

It is clear that the harsh appearance of buildings and cities was created with enemies in mind, but for inhabitants, for relatives and invited guests, they were not scary. The empty walls and closed gates created the first line of defense followed by very different and expressive images of the militant sentinels, ready to give off thunder and flashes of lightning, to spew fire and shoot. And then everything was transformed, as in a fairy tale giving the impression of peace, well-being and beauty.

The development of architectural decoration can be explained by the desire to better protect the walls of buildings from hostile influences, to show the power of magical energy surrounding them, which begins to flow as soon as the impassable outer shell is opened. On this basis, images of bristling and writhing zoomorphic creatures became appropriate. The outlines of the temples, filled with such creatures, found on the Novgorod miniatures of the socalled animal style, perfectly convey this idea. Chimeras on Gothic churches, and dragons especially popular in architecture of the Far East carried similar meaning.

In the Middle East, there was the tradition of depicting four fearsome winged animals surrounding and supporting the throne of a deity or an associated great ruler. They were called cerubs (gryffins) or biblical cherubs [12]. The book of Ezekiel says that they have wheels under them and constantly move one after another in one direction, that is, they rotate, forming a vortex — "Galgal" [Ezek., 10.13]. The face of God is hidden inside this vortex or clouds, inaccessible to the eyes of ordinary men [13]. The cherubs were determined as being of a fiery nature, relating to the higher angelic ranks, which included even the seraphims and the thrones (angelic ranks) [14]. These guardian angels were endowed with frightening dragon-like appearance [15].

There was a general opinion that pagan idols and their bloody cult sites made an opressive impression. The explanation lies, as it seems, in the protective function of the mythological characters surrounding the Shrines. These characters warned people about the danger of coming into contact with invisible forces. They kept out, threatened, and demanded sacrifices in order to approach the deity and 
receive a fraction of its immense power. And again, it was clear that in order to be worthy to stand before "bright eyes" of a great Lord, it is necessary to pass tests and certain initiations.

\section{From the MANIFESTATION OF THE MYSTERY TO ITS PROFANATION}

The world began to change markedly with the advent of new monotheistic religions. Pagan traditions long remained but without the same brutality, in a relaxed and rethought condition. Shortly after the baptism of Rus, Metropolitan Hilarion noted the coming of the new Testament Grace to replace the severe old Law [16]. The son of God appeared to the people as a Savior. The Christian Church retained the function of concealing the liturgical sacrament, but received a new architectural image - attracting and pleasing. Muslim mosques, madrasahs and mausoleums with their iced blue domes, precise silhouettes and exquisite ornaments also began to exude outside the radiance of the glory and beauty of God, without frightening effect. It can be said about Buddhist stupas, temples, datsans. It should be noted that the tendency to achieve architectural splendor, expressing the imperturbable greatness of a powerful God or divine ruler manifested itself in pagan times, especially in ancient civilizations, opposing themselves to the world of barbarians.

The Bible book of Genesis says that after the expulsion of Adam and Eve, the Lord "set in the East by the garden of Eden a cherub with a turning flaming sword to guard the path to the tree of life." [Gen., 3.24]. The sacred place should be completely hidden in an impregnable fortress, which is scary to approach. There is an analogy with the Holy of Holies of the Jewish temple. The altar space of a Christian church is also shrouded by "the fear of God". But it is partly opened and attracts the eyes and souls of the worshippers.

This opening of the veil of secrecy in the name of communion to the Truth was the definitive beginning of the development of new trends in architectural creativity. The hope for salvation, the atonement of sins, and the return to the Lord inspired both the customers and the masters, who increasingly turned to the highest speculative ideals. The heavenly image of the New Jerusalem, described in the revelation of John the Theologian, attracted with the crystal purity, absence of evil and the fact that God is there with people, as he was in Heaven. It is important to note that the gates of this city are always open: "its gates will not be locked during the day; and the night will not be there."[Rev., 21.26].

Beautiful buildings of not only religious but also secular purpose, with carved decorations, gilding, paintings and mosaics, could be associated with the Paradise, not hidden but reproduced in earthly reality. That attracted and delighted people who longed to get rid of the torments of this world. Such buildings became the adornment of the landscape as the centers of the divine grace spread. The illusion of the promised transformation of the world appeared. This is the essence of the shift from the middle
Ages of Modern times with its ideas of enlightenment, freedom, equality and brotherhood.

Patriarchal relations at the same time gave way to absolutism, which took on the mission of planting universal happiness on earth. This was the key to many practical successes, on the one hand, but also the intensification of social conflicts and the painful devaluation of the traditional worldview on the other. In Russia, it has led to a church schism with its far-reaching consequences. Geometrical accuracy, general composition, harmonic coherence of forms, the representativeness of facades and the grace of interiors has become more valued. Architects has begun to increase window sizes in older buildings, demonstrating their openness and light in contrast to the medieval gloom. It was as if all the secrets have been now revealed.

Returning to the topic of the house-yard-fortress touched upon at the beginning of the article, it should be noted that when the main parts were hiding in the depths, and the secondary ones came to the forebround, the external architectural forms of the dwelling were largely random and unpresentable. Now, in the new, imperial time, the main concern of architects was the achievement of presentable, impressive street facades of houses, because urban, public spaces were understood as something of self-value and indicative, state-significant, much more important than the cramped spaces of citizens' modest private life.

From the point of view of the adherents of the traditional culture that meant a metamorphosis threat called in Russia, according to tradition, lycanthropy. No wonder the old believers saw in Peter the Great ascended the throne as the Antichrist. Thoughts of this kind, fueled by the unjust voluntarism of the authorities against the background of waiting for the end of the world, have appeared before. With regard to the surge of decorativeness or patterned style, characteristic of Russian architecture of the XVII century, some contemporaries expressed concerns that it could be satanic in nature. [17]. The beauty of the church, and at the same time secular one, shone on all Russian land with unprecedented force. But has it come from God or was it a devilish delusion?

\section{CONCLUSION}

We can see a lot of ostentatious, far-fetched and theatrical features in the architecture of the last centuries. It can be seen that architects and artists tried very hard to create spectacular compositions to please customers and authorities, concerned primarily with the external representation of public spaces. The meaning of these compositions is not in hiding, but on the contrary, in the worldwide disclosure of their content, and not so much existing as invented and imposed on the audience by the powerful of this world.

Responding to the idea of S. O. Khan-Magomedov about two super styles - the order-based one and the non-orderbased I would like to say that the first of them was characterized not only by the use of the classical tectonic system: since the Renaissance, its main nutrient soil was the ever-increasing interest in history, generating scientific, 
cognitive, artistic and romantic approach to the development of heritage, first ancient, and then altogether unordinarymedieval and exotic. The second "super style" inherent in the avant-garde of the twentieth century, on the contrary, appealed to something timeless, abstract, geometric, not subject to the course of history. So, it is only necessary to recognize that it was born not in modern times but in ancient times, under the domination of religious consciousness. However, it requires a reservation that the avant-garde art known to us preferred to do without religion in its traditional sense. Or pretended to create a new quasireligion, relying on the subjective intuitiveness of the master [18].

Now architecture is in an unstable position between the same eclectic historicism and abstracted minimalism of "pure" forms. Theoretically, preference is given to the first in the name of maintaining continuity of the current urban context. But the commitment to the avant-garde style prevails, which, however, has also become a historical phenomenon. Architects tend to care less and less about timeless. The commission itself gives little reason to. The main attention is paid to the solution of urgent functional tasks.

The revival of religious architecture in Russia could help to improve the situation, but in this area it is more important for us to imitate recognizable patterns. Churches, moreover, have lost the opportunity to be the architectural dominants, as the city has been filled with huge volumes of multi-storey residential buildings and offices. What are the shells of these large-scale shelves hiding inside? Arrays of small cells, crammed in more or less costly cases of questionable aesthetic qualities indifferent to them. Sometimes architects manage to create impressive compositions, but now they have no original organic relationship between form and content because architects stopped to think about the inclusion of the sacramental beginning in the architectural creation. Everything has become mundane, rational, pragmatic and inherently transient.

How to deal with loss of the soul and meaning of contemporary mass architecture? It might be necessary, first of all, to try to return to the understanding of each building as an internally harmonious, integral organism, the microcosm possessing "selfness", the character of its own and an image - the spirit, and thus an internal secret. Then its architectural masses will once again serve as a kind of a garment, the shell that protects this secret, the spirit, its pulse. Architecture can be strict, closed, can have various degree of friendliness and openness, the only important thing is not to allow the deadening coldness inside of it hidden under the face of false prettiness. This, of course, is a very difficult task that requires a deep insight and responsibility from the architect. it might be obscure and uninteresting for the designer from the sphere of "technical aesthetics". So, for centuries, architecture played the role of both symbolic and quite real apotrope for the sacred hearth of true life hidden inside. The realization of this can help to return to modern architecture, at least in part, the lost status of the great life-building art.

\section{REFERENCES}

[1] Rappaport A. G. The collapse of modern architecture // Bashnya i labirint URL: http://papardes.blogspot.com/2018/04/3.html?q=смерть+архитектур ы (8.09.18).

[2] Eliade M. The sacred and the secular. Moscow, 1994, P. 22-47.

[3] Cosmological works in the books of Ancient Russia, Traditions. SPb., 2009, P. 70.

[4] Russian people. Their customs, rituals, traditions, superstitions and poetry. Edited by M. Zabylin. Moscow,1992, P. 330-334.

[5] Poznanskiy N. Charms. The experience of the study of the origin and development of charm formulas. Reprint of the edition of 1917, Moscow, 1995, p.255.

[6] Propp, V. Y. Historical roots of a fairy tale. 1986, P.59.

[7] Domostroy / edited by V. V. Kolesov. Moscow, 1990, P. 68.

[8] Baiburin A. K. Ritual in traditional culture. Structural and semantic analysis of East Slavic rites. SPb.,1993, P. 144-145.

[9] Afanasiev A. N. Poetic views of the Slavs on nature, Moscow, 1994, P.26-29.

[10] Afanasiev A. N. Poetic views of the Slavs on nature, Moscow, 1994, p. 30 .

[11] Maksimov S. V. Evil, unknown and power of the cross. Moscow, 1989, p. 115.

[12] Podosinov A.V. The symbols of the four evangelists. Their origin and meaning. Moscow, 2000, pp. 31-60.

[13] Bondarenko I. A. Architectural embodiment of the image of the Glory of the Lord // Architectural heritage. Issue.56. Moscow, 2012. pp. 515.

[14] Pseudo-Dionysius The Areopagite. On the heavenly Hierarchy. Translation from ancient Greek. Moscow, 1994, p. 45-46.

[15] Myths of the world. Encyclopedia in 2 volumes, edited by S. A. Tokarev. Vol.2. 1992, P. 427.

[16] Metropolitan Hilarion. Sermon on Law and Grace / translated by V. Derjaguin // Almanac of the bibliophile. M., 1989, Issue.26, p.155.

[17] Artistic and aesthetic culture of Ancient Russia. XI-XVII century. edited by V. V. Bychkov. Moscow,1996, P. 308-312.

[18] Khan-Magomedov S. O. Ivan Zholtovsky. Moscow, 2010. P. 7-17. 